\title{
Development of Illustration of Jakarta Environmental and Cultural Textbook in Elementary School Level
}

\author{
Ratih Mahardika ${ }^{1}$ \\ ${ }^{1}$ Visual Communication Design, Faculty of Creative Industry and Telematica, \\ Trilogi University, Jakarta, Indonesia \\ $\underline{{ }^{1} \text { ratihmahardika@trilogi.ac.id }}$
}

\begin{abstract}
Jakarta's environmental and cultural education (PLBJ) is one of the subjects needed to maintain the concept of valueof lifecommunity and Betawi cultural environment for future generations, particularly elementary school students. The material presented is not only in the form of description but is also in the form of illustrations. However, the composition between the descriptions and illustrations are not balanced and affect students' interest in reading at school. Illustrations displayed in book is important for elementary student. This is due to interesting illustrations stimulates children's curiosity and motivation to read books. Because of this, it is necessary to develop illustrations in accordance with the book material using methods educational research and development which have 4 stages of process (4D) which consist of definition (needs analysis of illustrations), design (illustration design), development (combining the results of illustrations with material in the form of descriptions), and dissemination (see responses from students and teachers concerned). The purpose of this research is to develop illustrations about the environment and culture of Jakarta, with emphasis on the traditional game known asDampuBulan which can be later used as part of the development of elementary school PLBJ subject matter.
\end{abstract}

Keywords: illustrations, textbooks, elementary schools, PLBJ

\section{INTRODUCTION}

The presence of illustrations is arguably mandatory on books, especially those intended for children, especially at the level of kindergarten or elementary school. An interesting illustration will stimulate children's curiosity and motivation to read books. Textbooks are very important accompanied by illustrations with the aim that children are interested in reading, help students understand the material, and are more enthusiastic in learning [1][2]. Illustration forms can be in the form of photos, drawings, graphics, and others with the aim of being a visual translation of material created in aesthetic corridors and design principles that can be understood and understood by the intended target audience [3]. Elementary school textbooks have illustrated images that have the main function as explanatory material and are inseparable from the material presented. Illustrations in textbooks do not involve a lot of varied images but are singular but are described in detail and in line with the concept of 
thinking children who are down to earth. So that the majority of illustrations elementary school textbooks illustratingobjects related to the local environment and culture [4].

One of the elementary school subjects whose content is related to the environment and the value of local cultural life is the Jakarta Cultural Environment Education (PLBJ) which has the aim that students have the ability to recognize concepts related to community life and the environment, especially Betawi culture. Then by studying PLBJ elementary students can have logical and critical abilities in solving problems in social life. Elementary students who are equipped with PLBJ are expected to later have a commitment and awareness of the social and cultural values that develop in the DKI Jakarta community. In addition, students by studying PLBJ can improve the ability to communicate, cooperate, and compete in a pluralistic society locally, nationally, and globally [5]. In the PLBJ book much can be learned, namely traditional games, folklore, Jakarta art, and matters relating to the environment. Based on the description of the PLBJ subjects, it can be concluded that the PLBJ is very important for elementary school students in the DKI Jakarta area as a metropolitan city whose life is very modern so it is necessary to preserve moral and cultural values through learning media that are of interest to elementary students.

One of the interesting materials to be studied further in the PLBJ books at elementary school level is traditional play material because currently it is difficult to find children who are still playing traditional games together. One game traditionally the PLBJ subject matter is DampuBulan (DB) which is in the second semester curriculum II grade. DB games are games that can be played by elementary school children, both boys and girls. DB does not require special equipment and must be purchased. Children can play DB in the yard and terrace of the house by making plots on the ground or floor according to the form agreed upon. These plots can be made using chalk, broken tiles, or with wooden sticks. The way to play it is also quite easy, children can use gacoan or playing tools in the form of metal pieces, broken stones, ceramics, tile, or glass cover. How to play DB by throwing the gacoan into the plot and the gacoan may not come out of the plot or hit the plot line. Then after the gacoan is thrown, the player jumps over each plot with one foot except for the plot that contains gacoan. As for the benefits that can be summarized from the DB game is to train body balance, train the ability of visual design, improve the ability of motion planning, and improve the ability to differentiate textures based on the sense of touch[6].

The condition of the second semester PLBJ book class with the theme of DB games can be identified by the composition of the material in it, which is $83 \%$ description (writing) and $17 \%$ visual (illustration of three girls playing in the field and without color). With the condition of the PLBJ book, learning activities tend to be done more by reading together in class and there are no other additional activities. Whereas children aged 6-11 years have a way of responding to picture books, namely responding to interactions between words and pictures; analyze the meaning of colors; reading body language; reading visual metaphors; observing and thinking; accept the challenges offered by the book; observe and study; and provide effective responses when reading picture story books [7][8]. Based on this description, it is very important that an elementary textbook be accompanied by illustrations in it, of course also the PLBJ book. So the purpose of this research is to develop illustrations about the environment and culture of Jakarta, especially the traditional game DB which can later be used as part of the development of Class II PLBJ subject matter. 


\section{METHOD}

This research was conducted in February - September 2018 which focused on the development of illustrations that are part of the PLBJ book material and of course this research is related to the educational context so that the method used is the method of research and development of education (educational research and development (ER\&D)). ER\&D is a process used to develop and test or validate educational products including textbooks, learning models, strategieslearning and others. In the method the ER\&D same as the R\&D method which has 4 process stages (4D) namely define, design, develop, and disseminate [9]. The define stage is the initial stage for defining illustrative problems in DB material. The Phase is design done by designing DB illustrations. The nextis to step develop an illustration with the DB material section by combining the material in the form of a description (sentence) and the illustration that has been designed. And at the final stage, namely disseminating to students and teachers of grade II at SDN Manggarai 17 Pagi, Tebet, South Jakarta so that new awareness and agreement arise that state that textbooks need to be accompanied by good and interesting illustrations.

\section{RESULT AND DISCUSSION}

Based on the description of the method mentioned earlier, each stage can be explained in more detail as follows:

\section{C.1. Define}

The problem raised in this study is an illustration of the traditional DB game in Class II PLBJ elementary school books. The illustrations in the PLBJ book have been identified as much as $17 \%$ of the total DB material. Following is a comparison of material in the form of a description (sentence) and illustration:

Development of Illustrations in Elementary School Level Jakarta Environmental and Cultural Textbooks

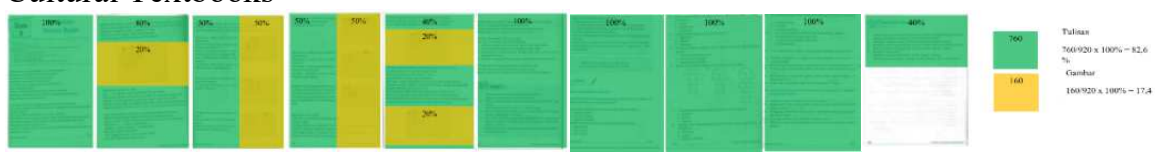

Figure 1. Comparison of PLBJ grade II elementary school material composition between description (sentence) and illustration (source image: author's personal documentation)

The picture above shows that the material in the form of illustrations is still lacking. Class II PLBJ elementary school books will certainly be read by children aged 7-9 years in relation to children's drawings must be able to include four criteria of visual language that is typical (easily recognizable), easy to identify spaces (environment), sequence of a setting that describes a series story, and overall composition [10]. Based on the visual language criteria, it can be identified the needs of the illustrations that will be developed include: 
Figure 2.Exixting illustration from DB

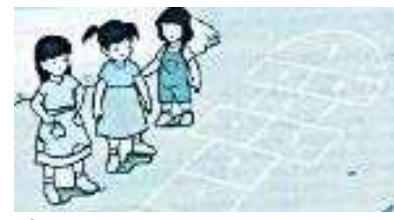

Table 1. Identification of the needs of the illustrations that will be developed

Illustration of DB players as many as three people namely Lusi, Mira, and Santi (by reading from left to right). The three of them are preparing to play DB. The

colors used in existing illustrations use only one color, namely gray and light blue

There are no supporting illustrations yet such as the tools used, how to determine the player's order, and how to play DB. a. three characters need to be portrayed in cheerful facial expressions like the expressions of children in general when playing together.

b. DB can be played on the lawn, porch, and terrain so that it is necessary to pay attention to the daily use of each character to make it look more appropriate.

Supporting illustrations need to be included to clarify how to play DB. Illustrations needed include: gacoan (broken stones or ceramics, pieces of metal, or glass cover), how to suten or hompimpa play sequence, and detailed DB playing conditions.

More detailed colors should be given in the illustrations made to make it more interesting for students to learn PLBJ material.

As for developing illustrations it is necessary to have a guide or visual reference (moodboard) related to DB both in terms of games, environment or related culture. Here moodboard used and collected from various sources:

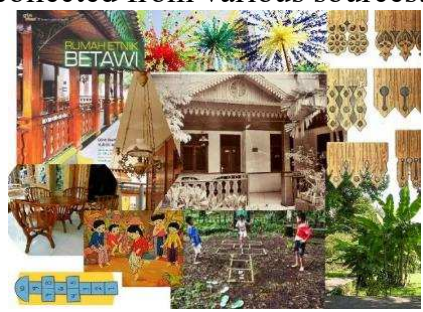

Figure 3. Moodboard reference DB illustration (image source: google image that layout in such a way by author)

Based on mood board the above it can be concluded that visual concept that refers to the visual language of the four criteria are as follows:

a. The specificity of the local culture that is Betawi culture will be visualized through a Betawi traditional house by paying attention to details on the wood carving ornaments on the roof \& walls of the porch, ancient lamp hangers, and a set of patio chairs made of wood and round in shape. 
b. Identification of the space that will be used as a background is a house yard that is still a lot of trees, porch, and a field around the house.

c. The background sequence in the series of stories is first, using the background of the home page with a bright atmosphere. Second, using the background of the terrace of the house with the atmosphere when it rains

d. The color composition that will be used using cheerful colors in accordance with the concept of gamestraditional DBand also in accordance with the colors of coconut roots as one of the characteristics of Betawi culture.

\section{C.2. Design The}

following is the development of illustrations that are adapted to the visual concept above:

Table 2. Development of illustrations based on existing illustrations (existing)

\begin{tabular}{l}
\hline existing \\
Figures: \\
Lusi, Mira, Santi
\end{tabular}

\section{C.3. Develop}

Some of the illustrations above are then combined in a layoutbook and compiled based on the traditional game materials of DB that already existed before. Here are 
some visualization displays of the results of the development of illustrations on the DB material contained in the PLBJ grade II elementary school book:

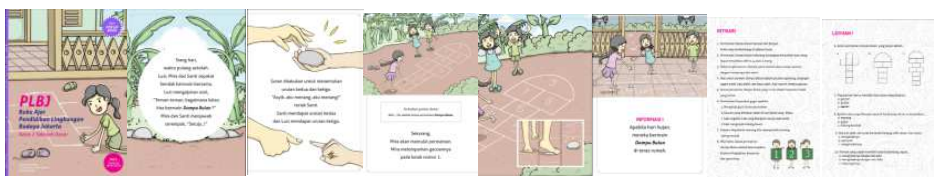

Figure 4. Examples of composition of the traditional DB game material between the description and illustration (source image: author)

\section{C.4. Disseminate}

Once the material has been completed di- DB layout the next process is the dissemination of material DB to the target users of the PLBJ book. The following documentation when disseminated to students and class II teachers by showing illustrations that have been developed in accordance with needs:

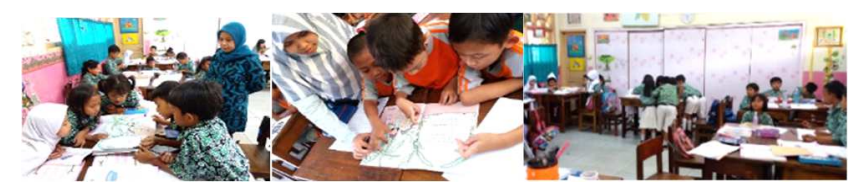

Figure 5. The process of dissemination to elementary school teachers and grade II after the DB material is developed.

In similar research developing elementary school level textbooks also have an interest in developing images as an effort to increase children's interest in reading and learning towards several sciences. Sothe learning outcomes are in accordance with the target learning outcomes[11][12] [13].

\section{d. CONCLUSION}

Development of illustrations needed for PLBJ books especially DB material is emphasized in several parts of the illustration namely character illustrations, background, and illustrationssupporting which are all related to DB. The development of character illustrations or characters is more adapted to the character of children and cheerful expressions when playing together. Detailed illustrations of the characters are given their respective characteristics in accordance with the characters introduced in the DB material so that they are easily recognized. It also needs to be considered in the details of the costumes or clothes used to better suit the habits of children playing everyday ingeneral (wearing t-shirts and flip-flops). Certainly more adapted to the concept of thinking children who are more down to earth. In the development of background illustrations, the Betawi environment and culture were introduced through the illustration of Betawi traditional house decoration and the atmosphere of the home page which is still full of trees so that students are reminded of the surrounding environment. While the supporting illustrations are also very necessary to help students better understand DB about the game tools that can be found in the surrounding environment.

DB materials with illustrations that have been developed and composed with material in the form of descriptions get a fairly good response from students and class II teachers of SDN Manggarai 17 Pagi, Tebet District, South Jakarta. The students are very enthusiastic about 
reading and learning DB material that has been given a new illustration. Whereas teachers feel students are more receptive to pictorial material quickly and teachers can develop ways of teaching in class.

\section{REFERENCES}

[1] A. S. Patria and S. Mutmainah, "Using Textbook Illustration as Media for Developing Character among Primary Students: Some Research-based Suggestion," J. Educ. Learn., vol. 12, no. 1, pp. 52-56, 2018.

[2] J. A. LaSpina, The visual turn and the transformation of the textbook. Routledge, 2014.

[3] J. A. Opara and N. S. Oguzor, "Inquiry instructional method and the school science curriculum," Curr. Res. J. Soc. Sci., vol. 3, no. 3, pp. 188-198, 2011.

[4] D. B. Golos, A. M. Moses, and K. A. Wolbers, "Culture or disability? Examining Deaf characters in children's book illustrations," Early Child. Educ. J., vol. 40, no. 4, pp. 239-249, 2012.

[5] N. Normah, "Peran Multimedia Dalam Pembelajaran Kebudayaan Betawi Bagi Siswa Sekolah Dasar," Cakrawala-Jurnal Hum., vol. 15, no. 2, 2015.

[6] S. Afrianur, "Analisis nilai-nilai karakter dalam permainan tradisional pada masyarakat Betawi," 2015.

[7] M. Salisbury and M. Styles, Children's picturebooks: The art of visual storytelling. Laurence King Publishing, 2012.

[8] M. Laitinen, "Thousands of words: a comparative study on the functions of pictorial illustrations in English language textbooks," 2014.

[9] P. H. Santoso, Rancang Bangun Alat Ukur Jarak Antara Dua Titik Dengan Menerapkan Hukum Pemantulan Cahaya Sebagai Media Pembelajaran Fisika Sma. Purwoko Haryadi Santoso, 2014.

[10] F. Hanisha and Y. A. Djalari, "Bahasa Visual, Gambar Anak, dan Ilustrasi Pada Buku Cergam Anak," J. Seni dan Reka Ranc. J. Ilm. Magister Desain, vol. 1, no. 1, pp. $63-$ 82, 2018.

[11] N. Prayogatama and P. Aditia, "Designing Book Illustrations Of Importance To Stay Away From Drugs For Children Elementary School," Bandung Creat. Mov. J., vol. 3, no. 1, 2016.

[12] J. Orrantia, D. Múñez, and J. Tarín, "Connecting goals and actions during reading: The role of illustrations," Read. Writ., vol. 27, no. 1, pp. 153-170, 2014.

[13] K. Saddhono, I. Mulyaningsih, I. K. Sudarsana, and R. T. Manurung, "Indonesian Language Teachers' Attitudes toward ICT Utilization in Learning for Elementary School in Surakarta," in Journal of Physics: Conference Series, 2019, vol. 1254, no. 1, p. 12062. 